\title{
ZAWODNOŚĆ RYNKU, PAŃSTWA I EKONOMII Z PERSPEKTYWY KRYZYSU FINANSOWEGO
}

\section{WSTĘP}

Ważne zmiany gospodarcze i polityczne przyczyniają się do istotnych przemian $\mathrm{w}$ metodologii badań ekonomicznych i prowadzą do zmiany zaleceń dotyczących kształtowania rzeczywistości ekonomiczno-społecznej. Wielki kryzys przyczynił się do tzw. rewolucji keynesowskiej, która w teorii oznaczała rozwój badań makroekonomicznych i przeniesienie akcentu z podażowych czynników wzrostu gospodarczego na czynniki popytowe, a w polityce ekonomicznej przyczyniła się do akceptacji polityki interwencjonistycznej skierowanej na regulację popytu i rozwój świadczeń socjalnych. Kryzys finansowy, który wystąpił w 2008 roku w Stanach Zjednoczonych, skłania wielu ekonomistów i polityków do sięgania do teorii Keynesa. Naturalne jest pytanie, czy właśnie w teorii i zaleceniach Keynesa należy szukać środków przeciwdziałania skutkom tego kryzysu. W ożywionej dyskusji wywołanej kryzysem padają często zarzuty pod adresem neoliberalizmu oraz stawiane są hipotezy, że obecna sytuacja w gospodarce światowej jest przejawem kryzysu międzynarodowych instytucji ekonomicznych, a nawet kapitalizmu czy gospodarki rynkowej. Atmosfera niektórych wystąpień, a także decyzje władz amerykańskich prowadzą do refleksji, że gdyby nie było wielkiego eksperymentu z gospodarką centralnie planowaną, moglibyśmy teraz mieć próby wprowadzenia jej na szerszą jeszcze skalę.

Dynamika i niepewność to wzajemnie powiązane cechy gospodarowania wynikające $z$ istoty gospodarki opartej na wolności i własności prywatnej. Wyjątkowa zmienność i niepewność obecnej sytuacji jest związana przede wszystkim z tym, że wspomniane podstawy gospodarki, którą określamy mianem rynkowej, podlegają głębokim zmianom, które nie są dostatecznie uwzględniane w badaniach ekonomicznych. Przyzwyczajenie do klasycznych funkcji instytucji gospodarki rynkowej sprawia czasem, że nawet ekonomiści instytucjonalni nie uwzględniają 
dostatecznie stopnia zmiany podstaw współczesnej gospodarki. Nieustanny spór między zwolennikami rozwiązań rynkowych i interwencjonistycznych oparty jest na tradycyjnym ujęciu zalet i wad rynku i centralnej regulacji. Celem artykułu jest nie tylko analiza zalet i zagrożeń alternatywnych mechanizmów regulacji z perspektywy kryzysu w gospodarce światowej, ale także próba oceny z tej perspektywy współczesnej ekonomii. Rozważania skoncentrowane są wokół trzech hipotez. Hipoteza pierwsza: błędne jest przeciwstawianie rynku i regulacji. Hipoteza druga: u podstaw kryzysu leży pogwałcenie zasad klasycznego liberalizmu, które ma źródła zarówno w polityce, jak i metodologii współczesnej ekonomii. Hipoteza trzecia: krytyczna analiza metodologii i logiki rozwoju myśli ekonomicznej w XX wieku może uzasadniać tezę o systematycznym błędzie doktryn, które zdominowały główny nurt ekonomii.

\section{UŁOMNOŚCI RYNKU CZY REGULACJI? - ŹLE POSTAWIONE PYTANIE}

Spory między zwolennikami rynku i państwa wydają się często sugerować, że proces regulacji jest przeciwieństwem i zastępowaniem rynku. Sam język sporu, używanie pojęć ułomności rynku, ułomności regulacji czy państwa - o takiej antynomii może świadczyć. Jeszcze bardziej przeciwieństwo mechanizmu rynkowego i centralnych działań regulacyjnych zakorzenione jest w świadomości. Wydaje się to zresztą całkowicie uzasadnione z perspektywy przeciwstawności gospodarki opartej na rynku i na centralnym planowaniu. Aby odejść od tego jednoznacznego przeciwstawiania rynku i państwa, należy odróżnić dwa rodzaje regulacji władzy centralnej: bezpośrednią regulację produkcji, która realizowana jest w systemie centralnego planowania, i tworzenie reguł postępowania ludzi w gospodarce opartej na wolności gospodarczej. Konieczność regulowania działalności gospodarczej w tym drugim znaczeniu jest głęboko zakorzeniona w klasycznym liberalizmie. Konieczność regulacji podstawowych zasad gospodarki rynkowej, czyli własności prywatnej i wolności, oraz znaczenie zaufania do sprawiedliwości władzy podkreślał już Adam Smith ${ }^{1}$. A sprzeciw zwolenników gospodarki rynkowej i liberalizmu wobec interwencji państwa był głównie sprzeciwem wobec działań arbitralnych oraz nakazów i zakazów, które uprzywilejowywały poszczególne

\footnotetext{
${ }^{1}$ „W państwie, gdzie nie ma regularnego wymiaru sprawiedliwości, gdzie ludność nie ma zapewnionej ochrony mienia, a prawo nie gwarantuje wykonania umów i gdzie wreszcie władza państwowa nie czuwa nad tym, by należności od osób, które są w stanie je uiścić, egzekwowano regularnie, tam handel i przemysł wkrótce podupadnie. Krótko mówiąc, handel i przemysł nie mogą rozwinąć się w żadnym państwie, gdzie nie ma zaufania do sprawiedliwości władz" (A. Smith, Badania nad natura i przyczynami bogactwa narodów, t. 2, Wydawnictwo Naukowe PWN, Warszawa 2007, s. 609).
} 
jednostki, grupy czy sektory gospodarki. Nie było to odrzucanie zgodnej z zasadą rządów prawa regulacji mającej na celu tworzenie jednakowych dla wszystkich ram transakcji rynkowych. Podkreślał to konsekwentnie znany ze swej bezkompromisowej krytyki socjalizmu i wierności wobec wolnego rynku Friedrich von Hayek. Znamienna i ważna z punktu widzenia współczesnych sporów o regulację rynków finansowych jest następująca wypowiedź Hayeka:

Z pewną być może przesadą, lecz nie bez uzasadnienia można by stwierdzić, że uznanie za fundamentalną zasadę liberalizmu braku aktywności państwa, nie zaś polityki świadomie przyjmującej za swe porządkujące reguły konkurencję, rynek i ceny oraz wykorzystującej egzekwowane przez rząd ramy prawne w celu spowodowania, by konkurencja była tak efektywna i dobroczynna, jak to tylko możliwe - z uznaniem jej tam i tylko tam, gdzie nie da się jej usprawnić - jest za upadek konkurencji odpowiedzialne w równym stopniu co aktywne wsparcie, jakiego rządy bezpośrednio czy pośrednio udzielały rozrostowi monopoli. [...]. Tradycyjna debata staje się wysoce niezadowalająca wszędzie tam, gdzie sugeruje się, że wraz z uznaniem zasad prywatnej własności i swobody zawierania umów, które rzeczywiście każdy liberał musi uznawać, wszystko jest rozwiązane - jak gdyby prawa własności czy umów były nam dane raz na zawsze w swej ostatecznej i najwłaściwszej postaci, to znaczy w postaci pozwalającej na możliwie najlepsze funkcjonowanie rynku. Dopiero jednak wtedy, gdy zgodzimy się co do tych zasad, zaczynają się prawdziwe problemy².

Regulacje formalne (prawo) i nieformalne (zasady moralne) leżą u podstaw sprzyjającego efektywności gospodarowania funkcjonowania rynku. $Z$ tej perspektywy, zamiast przeciwstawiać rynek i regulacje i rozpatrywać odrębnie ułomności rynku i państwa, należy skupić uwagę na dwóch problemach: na tym, jak regulować transakcje, aby ceny dobrze pełniły funkcję informacyjną i motywacyjną, i na tym, jak regulować działalność gospodarczą w interesie ogólnym, unikając zagrożeń, które z powodzeniem ujawnia teoria wyboru publicznego.

Przeciwstawianie ułomności rynku i regulacji związane jest $\mathrm{z}$ błędem myślenia nazwanym przez Harolda Demsetza sofizmatem nirwany (nirvana fallacy). Demsetz wskazał na niebezpieczeństwa wynikające $z$ analizy i oceny rzeczywistości gospodarczej opartej na konfrontacji z idealnym wzorcem. Ci, którzy przyjmują taki punkt widzenia (nirvana approach), poszukują różnic między rzeczywistością a ideałem i kiedy znajdują odstępstwa od ideału, wyciągają wniosek, że proces ekonomiczny charakteryzuje nieefektywność ${ }^{3}$. Z jednej strony, mamy

${ }^{2}$ F. A. Hayek, Indywidualizm i porządek ekonomiczny, Wydawnictwo Znak, Kraków 1998, s. 125 .

${ }^{3}$ H. Demsetz, Information and efficiency: another viewpoint, [w:] T. Cowen, E. Crampton (red.), Market Failure or Success. The Nerw Debate, Edward Elgar, Cheltenham-Northampton 2002, s. 107. 
do czynienia z identyfikacją wad rynku i przekonaniem, że rząd zawsze może istniejący stan udoskonalić, z drugiej - krytycy interwencjonizmu wskazują często wady polityki w taki sposób, jakby istniał „magiczny rynek”, który wszystkie problemy rozwiąże w doskonały sposób. Bardziej owocną metodą jest komparatywna analiza instytucjonalna, która polega na empirycznym badaniu różnych układów instytucjonalnych.

\section{FUNKCJE CEN Z PERSPEKTYWY KRYZYSU FINANSOWEGO}

Analiza przyczyn współczesnego kryzysu finansowego ujawnia $\mathrm{z}$ wielką ostrością słabości mechanizmu cenowego, które występowały zawsze, oraz prowadzi do wniosku, że innowacje finansowe, rodzaj regulacji, a czasem ich brak - to ważne czynniki wpływające na sposób funkcjonowania rynku, a w konsekwencji na funkcję informacyjną i motywacyjną cen. Za słabość mechanizmu cenowego można uznać to, iż informacyjna funkcja cen ulega osłabieniu w fazach drastycznych spadków i wzrostów aktywności uczestników gry rynkowej. Ma to szczególne znaczenie na rynku papierów wartościowych. To, że cel uczestników gry giełdowej - zysk wynikający z różnicy kursu kupna i sprzedaży jest funkcją zmieniających się periodycznie oczekiwań dotyczących kursów papierów wartościowych, powoduje, iż na rynkach finansowych zwykle nie działa prawo popytu, przywracające równowagę, lecz paradoks spekulacyjny kumulujący nierównowagę. Ceny na tych rynkach pełnią zatem funkcję informacyjną w szczególny sposób: informując o względnej rzadkości przedmiotów transakcji, oddają głównie stan nastrojów gospodarczych, wykazujących tendencje do irracjonalnej kumulacji. Jeżeli znaczenie i udział rynków finansowych w systemie gospodarczym rośnie, słabną siły przywracające równowagę, system ekonomiczny staje się bardziej podatny na zakłócenia.

Konieczność nowego spojrzenia na funkcje cen wynika także $z$ wprowadzenia do obrotu pochodnych instrumentów finansowych i ze skali wykorzystywania dźwigni finansowej. Innowacje na rynkach finansowych sprawiły, że krytycznie spojrzeć należy nie tylko na informacyjną funkcję samych instrumentów finansowych, ale także cen takich strategicznych dóbr, jak ropa naftowa. Tradycyjna doktryna przedstawia mechanizm cenowy jako oszczędny mechanizm przekazywania informacji. Rozwijając epistemologiczną argumentację za rynkiem, Hayek podkreślał, że w systemie rynkowym wystarczy niewiele wiedzy, by jego uczestnicy mogli podejmować właściwe decyzje. System cenowy pozwala na rozszerzenie zakresu wykorzystania zasobów poza obszar kontroli jednostkowego umysłu, uwalnia system ekonomiczny od potrzeby świadomej kontroli i tworzy bodźce skłaniające ludzi do podejmowania właściwych działań bez konieczności wyda- 
wania im poleceń. „Jest rzeczą cudowną - pisał Hayek - że w przypadku niedoboru surowca tysiące ludzi bez żadnego nakazu i mimo nieznajomości przyczyn widząc, wzrost ceny, zaczyna surowiec oszczędzać”".

Zmiany ceny ropy naftowej na rynku światowym w 2008 roku mogą być jednak przykładem osłabiania funkcji informacyjnej cen i mogą ilustrować pogląd, że rynek nie jest abstrakcyjnym instrumentem, którego działanie jest niezależne od celów i zasad ludzkiego działania. Funkcje i skutki rynku rozumianego jako splot transakcji będących przejawem dążenia ludzi do zaspokajania potrzeb, wśród których jest także dążenie do zysku, mogą zmieniać się wskutek wprowadzenia nowego przedmiotu obrotu, takiego jak transakcje terminowe. Paradoks polega na tym, że instrumenty, które rozwinięto w odpowiedzi na dużą zmienność stóp procentowych i kursów walut w celu zmniejszenia ryzyka, wykorzystywane są w celach spekulacyjnych i przyczyniły się do ogromnego wzrostu ryzyka w skali całego systemu.

Ceny ropy naftowej charakteryzuje $\mathrm{z}$ jednej strony tendencja wzrostowa, z drugiej zaś wielkie fluktuacje. Tendencja wzrostowa znajduje racjonalne wyjaśnienie we wzroście zapotrzebowania na ropę naftową wynikającym z dynamicznego wzrostu gospodarki chińskiej i indyjskiej. Ale te fundamentalne czynniki wzrostu ceny nie mogą wyjaśniać fluktuacji, które ujawniają zarówno średnie ceny roczne w okresach kilkuletnich, jak i gwałtowne zmiany obserwowane w bardzo krótkich okresach. Najbardziej drastycznym przykładem był rok 2008, w którym w lipcu średnia cena tego strategicznego surowca osiągnęła w USA 128 \$ za baryłkę, a w grudniu obniżyła się do $36,8 \$$. Fluktuacje te należy wiązać nie tyle ze zmianami realnych warunków gospodarowania, ile ze zmianami nastrojów gospodarczych, których znaczenie potęgowane jest przez możliwości, które stwarzają kontrakty terminowe. To, że można wykorzystać zmiany koniunktury gospodarczej do maksymalizacji zysków spekulacyjnych bez dokonywania realnych transakcji (wiążących się z koniecznością ponoszenia kosztów transportu i magazynowania), musi wpływać na częstotliwość operacji spekulacyjnych. To, że rozwój rynku instrumentów pochodnych, zmniejszając koszty transakcyjne, oddala rynki finansowe od procesów realnych i zwiększa skłonność do spekulacji, uświadamia, iż zmniejszanie kosztów transakcji może być zjawiskiem negatywnym. Wzmacnia to argumenty za opodatkowaniem transakcji finansowych.

Do rozwoju dyskusji wokół opodatkowania transakcji finansowych przyczyniła się bezpośrednio propozycja podatku Jamesa Tobina. Wcześniej jednak propozycję podatku, który zmniejszałby skłonność do spekulacji i działał dzięki temu

${ }^{4}$ F. A. Hayek, op. cit., s. 100.

${ }^{5}$ Energy Information Administration. Official Energy Statistics from the US Government, http://www.eia.doe.gov/pub/oil_gas/petroleum/data_publications/petroleum_marketing_annual/historical/2008/pdf/pmatab1.pdf (październik 2009). 
stabilizująco na koniunkturę, wysunął John Maynard Keynes. Szczególnej aktualności w obecnej sytuacji nabrały następujące spostrzeżenia zawarte w Ogólnej teorii zatrudnienia, procentu i pieniqdza:

W miarę ulepszania organizacji rynków występuje istotne niebezpieczeństwo, że spekulacja jednak weźmie górę nad przedsiębiorczością. [...]. Spekulanci mogą być nieszkodliwi, gdy są niczym piana na spokojnych wodach przedsiębiorczości. Ale sytuacja staje się poważna, gdy przedsiębiorczość zaczyna być pianą na wodach spekulacji. Gdy akumulacja kapitału w jakimś kraju staje się ubocznym produktem gry hazardowej, wyniki zawsze będą opłakane [...] Uważa się zazwyczaj, $\dot{z} \mathrm{e} w$ interesie publicznym leży, by domy gry były niedostępne i kosztowne. To samo słuszne jest, być może, w odniesieniu do giełd [...]. Gdy chodzi o ukrócenie przewagi spekulacji nad przedsiębiorczością w Stanach Zjednoczonych, bardzo celową reformą może okazać się wprowadzenie znacznego podatku państwowego od transakcji giełdowych ${ }^{6}$.

Spekulacja wpływa nie tylko na informacyjną funkcję cen, ale także na nie mniej ważną z punktu widzenia ideologii gospodarki rynkowej funkcję motywacyjną. Niezmiernie ważnym kryterium oceny gospodarki rynkowej jest jej zdolność do tworzenia instytucji motywujących do twórczości i wysiłków prowadzących do wzrostu produkcji służącej poprawie warunków ludzkiego bytu, do zwiększenia rzeczywistego bogactwa, a nie do przechwytywania tego bogactwa od innych. Jak obrazowo wyraził to Douglass North: „Jeżeli matryca instytucjonalna lepiej wynagradza piractwo (czy bardziej ogólnie: działania prowadzące do redystrybucji) niż działalność produkcyjną, wtedy uczenie się przyjmie formę uczenia się, jak być lepszym piratem"7.

$\mathrm{Na}$ ogół skupiamy się na zagrożeniach wynikających z redystrybucji będącej skutkiem podatków i polityki socjalnej. Ceny kształtujące się na wolnych rynkach traktowane są jako instrument motywacji służący wzrostowi produkcyjności. Kryzys pokazuje, że należy poddać krytycznej analizie ceny instrumentów finansowych z punktu widzenia ich funkcji redystrybucyjnej. W „normalnych” czasach niedostateczna uwaga poświęcana jest redystrybucji bogactwa poprzez system współczesnych rynków finansowych.

${ }^{6}$ J. M. Keynes, Ogólna teoria zatrudnienia, procentu i pieniadza, Wydawnictwo Naukowe PWN, Warszawa 2003, s. 139-141. Por. T. Kowalik, Kapitalizm kasyna, [w:] Kryzys. Przewodnik Krytyki Politycznej. Przyczyny, analizy, prognozy, Wydawnictwo Krytyki Politycznej, Warszawa 2009, s. 68.

${ }^{7}$ D. C. North, Institutions, Organizations and Market Competition, s. 10, http://129.3.20.41/ eps/eh/papers/9612/9612005.pdf (wrzesień 2009). 


\section{CZY U PODSTAW KRYZYSU LEŻY LIBERALIZM?}

Aby zająć stanowisko $\mathrm{w}$ dyskusji na temat znaczenia ideologii liberalnej w procesach podejmowania decyzji, które ostatecznie doprowadziły do kryzysu finansowego, należy najpierw określić, co rozumiemy przez pojęcia liberalizm i liberalna ekonomia. Jeżeli pod pojęciem liberalizmu ukrywa się wyobrażenie, że wolność transakcji dążących do zysku ludzi zapewnia stabilny wzrost gospodarczy niezależnie od jakości systemu pieniężnego i formalnych zasad, które wyznaczają ramy tych transakcji, to na postawione pytanie należy odpowiedzieć twierdząco. Jednak takie rozumienie liberalizmu jest błędne, choć niestety odpowiada ono nie tylko wyobrażeniu publicystów, ale także polityków i ekonomistów, nawet tak wpływowej postaci jak Alan Greenspan ${ }^{8}$.

Poszukując winnych kryzysu, należy przypomnieć, że liberalizm to doktryna wyrastająca z ekonomii klasycznej, w której akcentowano następujące zasady i ograniczenia w procesie gospodarowania:

- Bogactwo powstaje w sferze realnej, a nie pieniężnej;

- Podstawą racjonalnej gospodarki jest równowaga między dochodami i wydatkami;

- Inwestowanie wymaga oszczędzania, czyli ograniczenia bieżącej konsumpcji;

- Nadzieja wysokich zysków związana jest z wysokim ryzykiem;

- Popyt na dobra tworzą w istocie inne dobra, a nie pieniądz (prawo Saya). Postawową funkcją pieniądza jest zatem funkcja środka wymiany, a nie pobudzanie koniunktury.

Analiza przyczyn kryzysu prowadzi do wniosku, że powyższe zasady nie były respektowane.

Zgodnie akcentuje się przecież, że do kryzysu przyczynił się niekontrolowany rozwój bańki spekulacyjnej na rynku nieruchomości i na rynku kapitałowym, oraz dostrzega się związek tych procesów z polityką pieniężną, brakiem regulacji nowych instrumentów finansowych oraz niedostatecznym nadzorem systemu bankowego. Kryzys związany jest także z ogromną nierównowagą międzynarodowych przepływów kapitałowych i rosnącym zadłużeniem gospodarki amerykańskiej ${ }^{9}$. Wśród przyczyn kryzysu wymienia się z jednej strony brak regulacji, z dru-

${ }^{8}$ Swoje pojmowanie gospodarki rynkowej i ideologii liberalnej A. Greenspan ujawnił w trakcie przesłuchiwania go przez Komitet Nadzoru Bankowego Izby Reprezentantów Stanów Zjednoczonych. Zob. Moja ideologia jest btędna, [w:] Kryzys. Przewodnik Krytyki Politycznej..., s. 228.

${ }^{9} 14$ października 2009 r. dług publiczny wynosił prawie 12 bilionów dolarów. Od 28 września 2007 r. do 14 października 2009 r. wzrósł o 3,98 mld dolarów. Zob. U.S. National Debt Clock, http://www.brillig.com/debt_clock/ (14.10.2009). O zadłużeniu gospodarki amerykańskiej pisze W. M. Orłowski, Świat, który oszalat, czyli poradnik na ciekawe czasy, „Biblioteka Gazety Wyborczej", Warszawa 2008. 
giej zaś brak dyscypliny rynkowej. O ile to pierwsze oznacza niewywiązywanie się państwa $\mathrm{z}$ funkcji instytucjonalno-prawnej, o tyle to drugie przejawia się w tym, że podmioty transakcji rynkowych lekceważyły swoje ograniczenia budżetowe i nie potrafiły właściwie oszacować ryzyka, które niosły ich decyzje dotyczące konsumpcji, inwestycji i korzystania ze środków obcych.

Błędy popełniane zarówno przez podmioty odpowiedzialne za regulację, jak i banki oraz ich klientów były konsekwencją tego, że nikt nie był w stanie przewidywać ryzyka, które kumulowane było w całym systemie ekonomicznym wskutek błędnej polityki pieniężnej, rosnących nierównowag makroekonomicznych, rozwoju nowych instrumentów finansowych i niekontrolowanego wykorzystania dźwigni finansowej. Rosnąca kapitalizacja rynkowa, tworząc złudzenie rosnącego bogactwa, podtrzymywała konsumpcję, a hojny system bankowy dostarczał środków realizacji inwestycji na rynku mieszkaniowym i kapitałowym. Postępowano tak, jakby sfera finansowa mogła być stałą podstawą wzrostu bogactwa i dobrobytu.

Konfrontacja zasad klasycznego liberalizmu gospodarczego i przyczyn kryzysu prowadzi do wniosku, że zamiast pytać, czy winowajcą jest liberalizm, lepiej postawić pytanie, kto zawiódł bardziej: uczestnicy gry rynkowej czy twórcy reguł tej gry, albo jakie błędy popełniali jedni i drudzy.

Podstawowe błędy twórców reguł to błędna polityka pieniężna i brak regulacji nowych rynków. Formułuje się przypuszczenie, że u podstaw błędów czy braku regulacji leży to, że podmioty odpowiedzialne za regulację przyjmują punkt widzenia regulowanych (cognitive regulatory capture). Natomiast najważniejsze błędy uczestników gry rynkowej to błędna ocena własnych możliwości i ryzyka, nadmierna skłonność do konsumpcji, uleganie spekulacyjnej gorączce, krótkookresowa perspektywa podejmowanych decyzji, niedostateczne poczucie osobistej odpowiedzialności. Błędom uczestników rynku sprzyjały błędy polityki pieniężnej, brak regulacji, a także panująca ideologia ekonomiczna. $Z$ jednej strony, błędne rozumienie filozofii rynkowej, z drugiej - nadmierna skłonność do konsumpcji związana z oddziaływaniem ekonomii keynesowskiej. To ostatnie oznacza groźbę długookresowego zachwiania równowagi między konsumpcją teraźniejszą i przyszłą, a tym samym sprawiedliwości międzypokoleniowej. $Z$ tej perspektywy kryzys można pojmować także jako szansę odejścia od niebezpiecznych tendencji.

\section{ZAWODNOŚĆ EKONOMII}

Błędów, które leżą u podstaw kryzysu finansowego, nie można rozpatrywać w oderwaniu od krytycznej analizy stanu wiedzy ekonomicznej i logiki jej rozwoju. Obecna sytuacja zmusza do dyskusji o metodologicznych podstawach ekono- 
mii i długoletnich tendencjach rozwoju tej dyscypliny nauk społecznych. Okazuje się, że nauka, która cieszyła się opinią najbardziej rozwiniętej wśród nauk społecznych, w czasach najtrudniejszych nie ma odpowiedniej teorii, skazując wszystkich na błądzenie po omacku. Uzasadnia to sformułowanie bezwzględnej diagnozy, że mamy do czynienia $\mathrm{z}$ „systematycznym błędem profesji ekonomicznej” ${ }^{10}$.

Ten błąd związany jest $z$ metodologicznymi tendencjami w badaniach ekonomicznych znajdującymi wyraz w rozwoju ekonomii neoklasycznej i formalizmu. Wbrew swej nazwie ekonomia neoklasyczna rozwijała się w bardzo luźnym związku z ekonomią klasyczną, podobnie jak neoliberalizm odbiegł od oryginalnych idei liberalizmu klasycznego. Ekonomię oddalało od klasycznych źródeł konsekwentne dążenie do uściślenia analizy ekonomicznej i do zbliżenia teoretyczno-metodologicznego statusu ekonomii do nauk przyrodniczych. Pod wpływem tych dążeń koncepcja rynku i równowagi gospodarczej została sformalizowana i upowszechniło się pojmowanie ekonomii zgodne z definicją Lionela Robbinsa, która ignoruje problemy wiedzy, koordynacji i instytucji ${ }^{11}$. Analiza wzajemnych związków między cenami i ilościami dóbr i czynników produkcji przy założeniu danych zasobów i danych rozwiązań instytucjonalnych zastąpiła klasyczną analizę czynników rozwoju gospodarczego, uwzględniającą czynniki instytucjonalne. Założenie danych zasobów sprawiło, że analiza stała się statyczna; założenie danego układu instytucjonalnego spowodowało oderwanie analizy ekonomicznej od historycznego i społecznego podłoża ${ }^{12}$. To nowe ujęcie rynku zaczęło rzutować na interpretacje oryginalnych idei Adama Smitha. Prowadziło to w istocie do zubożenia ekonomii ortodoksyjnej o ważne idee obecne w ekonomii Smitha. Polaryzacja myśli ekonomicznej stawała się coraz wyraźniejsza. Ortodoksyjne myślenie wykluczało z pola badań instytucje i stawało się coraz bardziej ahistoryczne; mo-

${ }^{10}$ D. Colander i in., The Financial Crisis and Systematic Failure of Academic Economic, s. 2, http://www.debtdeflation.com/blogs/wp-content/uploads/papers/Dahlem_Report_EconCrisis021809.pdf (wrzesień 2009).

${ }^{11}$ Zdaniem Buchanana definicja Robbinsa sprawiła, że ekonomiści skoncentrowali się na kalkulacji i optymalizacji i przekształcili ekonomię w matematykę stosowaną. Przedmiotem badań uczynili abstrakcyjne ludzkie zachowanie, podczas gdy ludzkie zachowania są zawsze instytucjonalnie uwarunkowane. Zob. A. Marciano, Value and Exchange in Law and Economics: Buchanan versus Posner, „Review Austrian Economics” 2007, no. 2-3. Schotter z kolei zauważa, że definicja Robbinsa nie uwzględnia znaczenia zdolności jednostek do tworzenia instytucji i prowadzi do błędnego wniosku, że konkurencyjne rynki to jedyny mechanizm koordynacji. Zob. A. Schotter, The Economic Theory of Social Institutions, Cambridge University Press, Cambridge 2008, s. 5.

${ }^{12}$ Początkowe założenie twórców marginalizmu dotyczące stałości zasobów ani słynna definicja ekonomii Robbinsa nie oznaczają, że ekonomiści neoklasyczni nie zajmowali się problematyką dynamiki gospodarczej. Świadectwem tego zainteresowania są neoklasyczne teorie wzrostu. Problem polega na tym, że neoklasyczna dynamika opierała się na narzędziach teorii statycznej. Por. J. R. Hicks, Kapitat i wzrost, PWN, Warszawa 1978. 
nopol na analizę instytucjonalną zyskiwała ekonomiczna heterodoksja ${ }^{13}$. Opozycja wobec ekonomii neoklasycznej była domeną ekonomistów heterodoksyjnych i szkoły austriackiej, która także $z$ czasem znalazła się poza głównym nurtem ${ }^{14}$. Specyfika austriackiego podejścia polegała na eksponowaniu problemu wiedzy, niepewności i instytucji oraz pojmowaniu równowagi jako tendencji ujawniającej się w procesach gospodarczych, a nie idealnego stanu końcowego. Przekonanie, że te cechy przedmiotu badań ekonomicznych są nie do uchwycenia i zrozumienia za pomocą metod ilościowych, determinowało negatywny stosunek szkoły austriackiej do tych metod i do postępującej formalizacji teorii ekonomicznej.

Zarysowana powyżej tendencja rozwoju ekonomii została pogłębiona w latach 50. i 60. XX wieku. Zmiany, które wówczas zaszły, zostały określone mianem rewolucji formalistycznej ${ }^{15}$. Wysoki stopień abstrakcji, logiczny rygor dedukcyjnego wnioskowania, zastosowanie matematyki i generalny priorytet formy analizy ekonomicznej nad treścią - oto podstawowe znamiona tej rewolucji. Ekonomiści formalistyczni nie posługują się po prostu matematyką jako narzędziem, lecz stosują matematykę jako model poznania naukowego, a jako kryteria oceny badań ekonomicznych przyjmują kryteria matematyków. W efekcie dokonuje się selekcji materiału badawczego z punktu widzenia jego przydatności do formalistycznego modelowania i przestają mieć znaczenie dowody empiryczne. Wiodącą rolę w procesie formalizacji teorii ekonomicznej odegrała praca Kennetha Arrowa i Gerarda Debreu Existance of Equillibrium for Competitive Economy (1954), w której przeprowadzono dowód istnienia rozwiązania równowagi ogólnej Walrasa ${ }^{16}$. Rewolucja formalistyczna oznaczała, że ekonomia w swym głównym nurcie przestała być nauką posługującą się naturalnym językiem i stosunkowo prostymi technikami statystycznymi i stała się nauką, w której sprawdzianem wartości naukowej jest rygoryzm dedukcyjnego rozumowania i zastosowanie wyrafinowanych technik

${ }^{13}$ Należy zgodzić się z Richardem Nelsonem, że koncentracja na hipotetycznym stanie równowagi i eliminacja aspektów instytucjonalnych i problemów rozwoju - to przejawy zawężania perspektywy intelektualnej ekonomii i odchodzenia od podejścia charakterystycznego nie tylko dla Smitha i Marksa, ale także Marshalla. Zob. R. R. Nelson, Bringing institutions into evolutionary growth theory, "Journal of Evolutionary Economics” 2002, no. 12.

${ }^{14}$ Różnice między szkołą austriacką rozwijającą poglądy Mengera a teoretykami równowagi ogólnej rozwijającymi model Walrasa ujawniły się jednoznacznie pod wpływem słynnego sporu o racjonalność gospodarki socjalistycznej. Okazało się wówczas, że różnice te są pod pewnymi względami większe niż różnice między ekonomią klasyczną a neoklasyczną. Zob. L. Makowski, J. Ostroy, Perfect Competition and the Creativity of the Market, "Journal of Economic Literature” 2001, no. 2; J. Godłów-Legiędź, Model socjalizmu rynkowego Oskara Langego a spór o paradygmat ekonomii, [w:] Z. Sadowski (red.), Oskar Lange a wspótczesność, Wydawnictwo PTE, Warszawa 2005.

${ }^{15}$ M. Blaug, The Formalist Revolution of the 1950s, "Journal of the History of Economic Thought" 2003, no. 2.

${ }^{16}$ Ibidem, s. 145. 
matematycznych. Jedną z najbardziej krytycznych opinii o tej rewolucji wypowiedział Mark Blaug: „Jeżeli w ogóle możemy określić początek tej choroby, to było to opublikowanie w 1954 r. słynnej pracy laureatów Nagrody Nobla Kennetha Arrowa i Gerarda Debreu; to ta praca wyznaczyła początek tego rakowatego rozwoju w samym centrum mikroekonomii" ${ }^{17}$.

Formalizm w nie mniejszym stopniu dotknął rozwijającą się wówczas z wielkim rozmachem w związku z rewolucją keynesowską makroekonomię. Jakkolwiek sam Keynes podkreślał specyfikę ekonomii jako nauki społecznej, był sceptyczny wobec ekonometrii i koncentrował się na problemach nierównowagi, inspirowana jego teorią makroekonomia została zdominowana przez podejście formalistyczno-modelowe, czego wyrazem był model IS-LM i tzw. synteza neoklasyczna ${ }^{18}$.

W latach 70.XX wieku nastąpiła ważna zmiana ideologiczna - odwrót od keynesowskiego interwencjonizmu, ale metodologiczne tendencje nie uległy zmianie. Formalistyczne podejście stało się podstawą argumentów na rzecz ideologii wolnorynkowej. Szczególną rolę odegrała hipoteza racjonalnych oczekiwań jako podstawa nowej makroekonomii klasycznej. Według tej hipotezy ludzie podejmujący decyzje ekonomiczne potrafią wyciągać wnioski ze swoich błędów i uczą się, czyli wykorzystują swoje intelektualne możliwości do zrozumienia sposobu funkcjonowania gospodarki i dostosowania swych decyzji do zmieniających się reguł działania. W świetle obecnej sytuacji w gospodarce światowej i ujawnionej zawodności prognoz ekonomicznych warto przypomnieć tezę Mutha, która była punktem wyjścia HRO Lucasa i Sargenta: „skoro oczekiwania są opartymi na informacjach prognozami przyszłych wydarzeń, to są one w zasadzie tym samym, co przewidywania dostarczone przez odpowiednią teorię ekonomiczną" ${ }^{19}$. Kryzys finansowy i sytuacja globalnej niepewności sprawiają, że obecnie bliżsi jesteśmy przekonania, że zarówno decyzje jednostek, jak i prognozy ekonomistów moga być obarczone systematycznymi błędami ${ }^{20}$.

${ }^{17}$ M. Blaug, Ugly Currents in Modern Economics, cyt. za: D. Wade Hands, Did Milton Friedman's Methodology License the Formalist Revolution, "Journal of Economic Methodology" 2003, no. 4 , s. 509 .

${ }^{18}$ Model IS-LM udowadniał przydatność walrasowskiego modelu równowagi ogólnej i pozwalał na uprawianie matematycznego modelowania w badaniach i w procesie nauczania. Interpretacja ekonomii Keynesa w postaci modelu IS-LM spowodowała usunięcie na margines tych wątków idei keynesowskich, które korespondowały z myślą instytucjonalną, a nawet austriacką, i umożliwiła tryumf rewolucji formalistycznej, a jednocześnie pozwoliła zachować istotne filary ekonomii neoklasycznej.

${ }^{19}$ B. Snowdon, H. Vane, P. Wynarczyk, Wspótczesne nurty teorii makroekonomii, Wydawnictwo Naukowe PWN, Warszawa 1998, s. 200.

${ }^{20}$ Jakkolwiek koncepcja racjonalności dominująca w głównym nurcie ekonomii zasługuje na krytykę, to należy przyznać, że generalny wniosek twórców nowej makroekonomii klasycznej, że efektem polityki uznaniowej jest inflacja i zwiększenie niepewności w procesach gospodarczych, zasługuje na uwagę w świetle sytuacji w gospodarce światowej. 
Rola, którą odegrało w rozwoju sytuacji kryzysowej wykorzystanie nowych instrumentów finansowych, może uzasadniać tezę, że koncepcja racjonalności jako maksymalizacji, niedocenianie problemu instytucji i koordynacji $\mathrm{w}$ połączeniu z fascynacją ideą kontroli i wiarą w możliwości tkwiące w narzędziach matematycznych - to źródła myślenia i działania, które można uznać za nowy typ inżynierii społecznej. Bezpośrednim wyrazem tej postawy jest rozwój matematycznych metod określania ryzyka i ich zastosowanie, tak jakby wykorzystanie matematyki finansowej gwarantowało przezwyciężenie prawidłowości, że nadzieja wysokiej stopy zysku jest zazwyczaj związana z koniecznością podjęcia wysokiego ryzyka. Wiara w matematyczny rygor narzędzi wyceny ryzyka instrumentów finansowych i oceny kondycji finansowej agencji ratingowych stwarzała dość powszechną iluzję, że wszystko jest pod kontrolą, podczas gdy bieg wypadków pokazał, że instrumenty pochodne przyczyniły się do zwiększenia poziomu ryzyka w systemie ekonomicznym ${ }^{21}$.

Spektakularnego przykładu zawodności tego sposobu podejścia do problemów ekonomicznych dostarczyli laureaci Nagrody Nobla z 1997 roku, nagrodzeni za opracowanie metody wyceny instrumentów pochodnych: Myron S. Scholes i Robert C. Merton. Przekonywali oni, że instrumenty pochodne przyczyniają się do rozwiązania problemu asymetrii informacji i że dzięki nieregulowanemu obrotowi tymi instrumentami klienci otrzymują lepsze usługi finansowe niższym kosztem. Scholes w swym wykładzie powiedział m.in.:

Banki inwestycyjne już nie tylko organizują transakcje i pełnią funkcje doradcze, ale przyjęły nowe podejście i zaczęły świadczyć usługi bardziej zintegrowane, skierowane na rozwiązywanie złożonych problemów swoich klientów na całym świecie. Dynamiczny rozwój teorii finansów sprawił, że instytucje finansowe mogą zaspokajać te wyrafinowane potrzeby efektywniej i niższym kosztem, niż było to możliwe wcześniej. Mariaż szkół i instytutów ekonomicznych z inżynierami, matematykami, fizykami i informatykami doprowadził do skuteczniejszych i tańszych technik finansowych umożliwiających rozwiązywanie problemów klientów ${ }^{22}$.

${ }^{21}$ Innowacje na rynkach finansowych obiecujące zmniejszenie ryzyka doprowadziły do jego zwiększenia w dwojaki sposób. Po pierwsze, wykorzystanie nowych instrumentów finansowych przyczyniło się do powstania nowych powiązań w systemie ekonomicznym i tym samym system ten stał się bardziej wrażliwy na wszelkie zmiany i kumulację nierównowagi. Po drugie, przekonanie, że dzięki nowym rozwiązaniom zmniejszyło się ryzyko inwestycji, prowadziło do zachowań bardziej ryzykownych, do zmniejszenia dyscypliny ekonomicznej i ignorowania ograniczenia budżetowego.

${ }_{22}$ M. S. Scholes, Derivatives in a Dynamic Environment, Nobel Lecture, December 9, 1997, s. 141, http://nobelprize.org/nobel_prizes/economics/laureates/1997/scholes-lecture.pdf (październik 2009). Z punktu widzenia opisanego podejścia interesujące jest stanowisko Aleksandra Jakimowicza. Rozważając nowe możliwości, które otwiera teoria chaosu, pisze on, że z teorii tej wynika nie- 
Stosowanie inżynierii finansowej i jej skutki są także ważnymi argumentami w dyskusji o aplikacyjnych wartościach teorii ekonomicznych. Rola instrumentów pochodnych w kryzysie uzasadnia zarzut wobec autorów abstrakcyjnych modeli matematycznych, że nie ujawniają w dostatecznym stopniu założeń swych modeli, a w efekcie ograniczeń ich zastosowań. Klasyczne rozwiązanie dotyczące cen opcji Blacka-Scholesa-Mertona wymaga spełnienia tak rygorystycznych założeń, jak zerowe koszty transakcji, brak korelacji czasowych, gaussowski charakter fluktuacji. Ponieważ żadne $z$ tych założeń na rynkach finansowych nie jest spełnione, strategia unikania ryzyka oparta na tym modelu musi zawodzić. Nowe spojrzenie i nadzieje wiąże się z wprowadzeniem metod fizyki do inżynierii finansowej ${ }^{23}$.

Odpowiedzialność ekonomii za kryzys związana jest nie tylko ze skłonnością do formalizmu, ale także z panującą ideologią wzrostu gospodarczego i wiarą w możliwości polityki stabilizacyjnej ${ }^{24}$. Przekonanie, że wzrost mierzony produktem krajowym brutto jest niekwestionowanym celem oraz że odpowiednia polityka pozwala uniknąć okresów spowolnienia aktywności gospodarczej - to podstawowe przesłanki skłonności rządów do stosowania w całym cyklu metod pobudzania gospodarki, które Keynes zalecał w okresie kryzysu. Nawiązując obecnie do nauk Keynesa, należy uwzględniać nie tylko nieuchronność polityki dyskrecjonalnej w kryzysie, ale także wpływ idei autora Ogólnej teorii na stosowanie ekspansywnej polityki monetarnej i fiskalnej w okresach spowolnienia wzrostu oraz na kształtowanie postaw konsumpcyjnych i niebezpieczne zmniejszenie skłonności do oszczędzania ${ }^{25}$.

możliwość przewidywania przyszłości i że teoria ta oznacza fiasko długofalowych metod sterowania gospodarką oraz zakwestionowanie znacznej części dotychczasowego dorobku ekonomii. Mimo to autor uważa, że sytuacja nie jest beznadziejna, o czym świadczą spektakularne sukcesy specjalistów od chaosu (fizyków) na rynkach finansowych. Okazało się bowiem, że chaos może być kontrolowany. Zob. A. Jakimowicz, Od Keynesa do teorii chaosu, Wydawnictwo Naukowe PWN, Warszawa 2003 , s. 405.

${ }^{23}$ Z. Burda, Fizyka i zarzadzanie ryzykiem finansowym, http://postepy.fuw.edu.pl/zjazdy /2005-Warszawa/PF-2006-3-Burda.pdf (10.10.2009).

${ }^{24}$ Trudność prognozowania przebiegu zjawisk ekonomicznych wynika $\mathrm{z}$ deformacji cyklu i związana jest z nieliniową naturą systemu gospodarczego. Mimo stworzonych przez rozwój techniki komputerowej możliwości przetwarzania ogromnych ilości danych, przydatność prognoz jest zatem niewielka. Znamienne jest jednak, że zdaniem wielu ekonomistów ograniczone możliwości prognozowania w makroekonomii nie powinny stanowić przeszkody w postawieniu właściwej diagnozy sytuacji gospodarczej i podjęciu odpowiedniej polityki stabilizacyjnej. Zob. A. Jakimowicz, op. cit., s. 380-381.

${ }^{25}$ Niezwykle trafną diagnozę tendencji panującej w myśleniu ekonomicznym teoretyków, polityków i zwykłych ludzi w drugiej poł. XX w. przedstawił już na początku lat 80 . Knut Burchardt. Zauważa on m.in., że dążenie do unikania kryzysów i obietnica stabilnego wzrostu w niebezpieczny sposób zmieniają prywatną i publiczną moralność wszystkich uczestników życia gospodarczego, a w konsekwencji ich zachowania. „Stabilność uznano za «dobro publiczne», którym darmo dysponować mogą wszyscy. [...] Na podobnej zasadzie przedsiębiorcy w swoich planach inwestycyjnych wyzbywali się w coraz większym stopniu obaw. Skoro nie miało więcej dojść do 


\section{ZAKOŃCZENIE}

Wskazując metodologiczne błędy i ideologiczne tendencje ekonomii z perspektywy obecnego kryzysu, można jednak mieć nadzieję, że ujawni się ostatecznie jego pozytywny wpływ na ewolucję instytucji społecznych i ewolucję samej ekonomii. Może kryzys, ujawniając błędność nie tylko decyzji alokacyjnych, ale przede wszystkim decyzji regulacyjnych i naszych przekonań, pozwoli dokonać modyfikacji istniejącego systemu społecznego. Na gruncie ekonomii kryzys może przyczynić się do odejścia od schematu nauki ukształtowanego w XVII wieku pod wpływem mechaniki Newtonowskiej, schematu opartego na założeniu, że „świat jest prosty i rządzą nim fundamentalne prawa, zachowujące moc bez względu na kierunek strzałki czasu"26. Tej wizji świata odpowiadał schemat myślenia naukowego ukształtowany przez matematyków i ta wizja świata leży u podstaw ekonomii neoklasycznej, formalizacji i dychotomicznego ujmowania wartości ekonomicznych i etycznych. Paradoksalnie, ekonomia pragnąca zawsze powielać model fizyki pozostaje wierna modelowi nauki „twardej” w sytuacji, gdy teoria kwantowa zmieniła punkt widzenia fizyków. Uwypukliła bogactwo realnego świata, uświadomiła, że nie można go opisać za pomocą jednej struktury logicznej i że na wszystkich szczeblach oglądu rzeczywistość zawiera w sobie zasadniczy element konceptualizacji ${ }^{27}$.

$Z$ jednej strony, zmiany wyobrażeń o naturze świata mające podstawę w naukach przyrodniczych, z drugiej zaś - nieoczekiwany przez większość stan niepewności w gospodarce światowej potwierdzają wniosek o konieczności zmian w sposobie uprawiania ekonomii. Niezależnie od szans, jakie stworzyć może rozwój ekonomii eksperymentalnej albo teoria chaosu, nasuwa się wniosek, że zmiana polegać powinna na rozszerzeniu spektrum badanych zjawisk i większej otwartości metodologicznej. Ograniczone efekty poznawcze i praktyczne matematycznej ekonomii potwierdzają stanowisko, że ekonomia powinna powrócić do podejścia metodologicznego prezentowanego przez Alfreda Marshalla, który wi-

powszechnego kryzysu, ryzyko inwestycji kapitału zdawało się mniejsze. Dlaczego zatem nie pogodzić się z wyższym zadłużeniem? I dla banków niemal pewnikiem stało się przekonanie, że ogłaszanie upadłości w stylu wczesnych lat trzydziestych nie powtórzy się nigdy, ponieważ centralny bank emisyjny wypełni oczywiście funkcję lender of last resort. Dlaczego zatem nie obniżać stale udziału własnego kapitału?” (K. Burchardt, Przemiany w myśleniu o kryzysach gospodarczych, [w:] O kryzysie. Rozmowy w Castel Gandolfo, Instytut Nauk o Człowieku w Wiedniu, Res Publica, Warszawa 1990, s. 126).

${ }^{26}$ I. Prigogine, I. Stengers, Z chaosu ku porzadkowi. Nowy dialog cztowieka z przyroda, Państwowy Instytut Wydawniczy, Warszawa 1990, s. 22.

${ }^{27}$ Ibidem, s. 242. Zasada nieoznaczoności Heisenberga i jej rozszerzenie w postaci zasady komplementarności Bohra zmuszają do odejścia od klasycznego ujęcia determinizmu i obiektywności. Zależność opisu układu kwantowego od układu pomiarowego ujawnia, że nie mamy dostępu do rzeczywistego przedmiotu badania. 
dział w ekonomii miejsce dla różnych metod badawczych. Dopóki nie pojawią się nowe możliwości analizy formalnej pozwalające ująć bogactwo świata społecznego, postępowi badań ekonomicznych służyć może zachowanie większej równowagi między analizą formalną, instytucjonalną i metodami eksperymentalnymi. A największym być może problemem ekonomicznej profesji jest brak współpracy tych trzech sposobów poznawania rzeczywistości gospodarczej.

\section{FAILURE OF THE MARKET, STATE AND ECONOMICS FROM THE PERSPECTIVE OF THE FINANCIAL CRISIS}

SUMMARY

The perennial conflict between the supporters of market solutions and interventionism is based on contrasting the market with regulation. The aim of this article is to analyze the opportunities and threats faced by alternative regulation mechanisms from the perspective of the crisis in the global economy, as well as to give an account of contemporary economics from this angle. The article is focused around three hypotheses. First, it is a mistake to put the market system and regulation in opposition to each other. Second, the underlying cause of the crisis is the violation of classical liberalism rules resulting both from politics and the methodology of contemporary economics. Third, critical analysis of the methodology and logic of the development of $20^{\text {th }}$ century economic thought may point to a systematic error in the doctrines which have dominated mainstream economics. 
